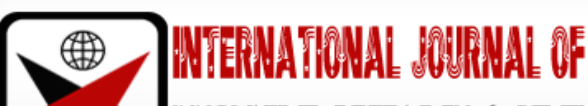

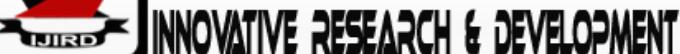

ISSN 2278-0211 (Online)

\section{Corner Shops and City Development in Uyo Metropolis, Nigeria}

\begin{tabular}{|c|}
\hline Koffi, Ayadu Edwin \\
Lecturer, Department of Urban and Regional Planning, \\
Akwa Ibom State Polytechnic, Ikot Ekpene, Nigeria \\
Uko Aniema Uwah \\
Assistance Lecturer, Department of Urban and Regional Planning, \\
Akwa Ibom State Polytechnic, Ikot Ekpene, Nigeria \\
\hline
\end{tabular}

\begin{abstract}
:
City development is achieve-able through the proper arrangement of the various land uses within a specific place where there is heterogeneity of characters with a place (City). Land uses such as; commercial, residential, industrial, public, semi-public, recreational and road when manipulated in a harmonious sense brings an expected result. This is to say that none of these land uses can single out itself to make-up a city rather the synergy of all these land uses. This study aimed at introducing small commercial activities at suitable intersections in the study area. To achieve this aim, a careful study was conducted on the traffic system in Uyo Core to identify the trend of movement of people as well as demand and supply of immediate needed goods and services to really select the intersection and needed service. This study focused on the design principle specifically that of 'variety' and economic principle of demand and supply. The study area was divided into seven (7) strata taking into considerations the street guide of Uyo. Oral interview, personal observation, and structured questionnaires form the basis of data collection and elicit information on the suitable intersection for siting of the corner shops in Uyo metropolis. The study concluded that in order to solve the problems of careless building of kiosks, selling on the traffic point and illegal shops along the roads, there is need for organized corner shops, this as well will increase the revenue base of the government, reduce economic waste and enhance the improvement of streetscape in Uyo metropolis.
\end{abstract}

Keywords: Corner shops, physical environment, city development, Uyo metropolis, Nigeria

\section{Introduction}

Nigerian cities have undergone radical changes in their physical forms, not only by territorial expansion, but also through internal physical transformations over the last decades (Idowu, 2013). These changes occur in two broad perspectives; the spontaneous and deliberate perspectives. Any city or town which experiences physical developmental changes without a specific guide is known to have spontaneous development (Ekandem et. al., 2014).While on the other hand; a one that undergoes planned and systematic dynamism is known to be deliberately developed (Alabi M. 0. and Akinbode A. 2010). Spontaneous development takes origin from specific nodes or intersections, with incessant increase in physical structures characterized predominantly by commercial activities that have little or no central control mechanism. From the designer's view, spontaneous development lacks "Order and Spatial Form Composition" it does not preserve the space for the future instead, brings about incompatibility of land uses and in future, it beckons for restructuring "Urban or City Renewal". Spontaneous city development is primarily a feature of the developing cities, as these urban centre grow, there is demographic absorbers, urban areas by their sheer size, create complex and multifaceted problems on scales never experienced before, (Olujimi, 2009).

The use of a Master Plan to control development makes city development deliberate. The Master Plan specifies current social, economic, political trends in accordance with the various indices for making that extent of development in the city acceptable by the people.

In Uyo, City development is viewed from these two perspectives. Originally, it developed spontaneously right from the pre-colonial era, where the present Ibom Connection which is the core of the city was just an intersection of major roads that distributed traffic to and from other parts of the state. This point was where the local people met on weekly basis to exchange their resources economically. Evolution and history reveal that the city developmental trend in Uyo follows socio-political development whereby the townscape and the morphology change accordingly (Udom, 2003).

In 1988, the creation of Akwa Ibom State juxtaposed the advent of the Master Plan which brought series of changes whereby the Urban Forms and City characters were altered. Many physical structures were destroyed and some integrated to give the feelings of what is today seen as the Capital City of Uyo (Usoro, 2010). 
In order to make ends meet, demand and supply cannot be pushed aside, people engaged in various commercial activities which were and are located at the various nodes (intersections). The influx of people into Uyo for different commercial activities gives Uyo another looks from what it was in the initial sense. As a result, congestion, pollution, traffic issues, insecurity, theft, and public nuisance were increasing every day. In attempt to remedy this problem the government of Akwa Ibom State made several efforts to restructure the city of Uyo to ensure a better living as much as possible. Such efforts led to the demolition of illegal shops along the streets of Uyo as well re-structure the streets design (Usoro, 2014). Adversely, this public decision has affected the private lives of the people negatively, due to damages done on properties.

In order to reconcile this difference (public and private) there is need to once again restructure the townscape by providing corner shops at every designated intersection, designed to provide for safety, commercial activities, passive recreational activities, conveniences, and aesthetics to achieve a descent cityscape in Uyo. This shall bring about increase in revenue to the Government, encourage private commercial activities and proffer a solution to traffic congestion in the city. In view of the above, the study aimed at introducing corner shops at specific road intersections in Uyo metropolis that would be beneficial for both the public and interested private retail commercial operators in order to enhance streetscape of the environment and promote development in the city. With the following objectives, to identify suitable intersections for corner shops, mark out space at each intersection for the corner shop, and produce a suitable design for the corner shop.

\section{Historical Perspective}

\subsection{Urbanization}

Urbanization, which refers to the expansion in the proportion of a population living in urban areas, it is one of the major social transformations, sweeping the globe. It represents the movement of people from rural areas to urban areas with population growth equating to urban migration. A United Nation's Report notes that the global urban population has quadrupled since 1950s, and cities of the developing world now account for over 90 percent of the world urban growth. A population estimate indicates that at a certain point in 2007, the world's urban population will equal the world's rural population for the first time in history. The growth in the urban population will continue to rise, projected to reach almost 5 billion in 2030. Much of this urbanization is predicted to take place in the developing world, with Asia and Africa having the largest urban populations. Current reports also indicate that more than half of the world's population now lives in urban areas, and by the year 2050, 70 percent will be city dwellers, with cities and towns in Asia and Africa registering the biggest growth. Consequently, urban population is anticipated to grow on an average $2.3 \%$ per year in the developing world between 2000 and 2030 (United Nation, 2018).

Nigeria has been no exception to this trend as it has one of the highest urban growth, it experiences a fast rate of urbanization growth in the world, and its experience has also been unique in scale, pervasiveness and historical antecedents. This process has resulted in a very dense network of urban centres.7\% of Nigerians lived in urban centres in the 1930 s, and $10 \%$ in 1950, by 1970, 1980 and 1990, 20\%, 27\% and 35\% lived in the cities respectively. Over $40 \%$ of Nigerians now live-in urban centres of varying sizes (United Nation, 2018).

\subsection{Urban Design Element}

The Urban Design Element guides public and private development to create a city that is diverse, people oriented, aesthetically appealing, and functionally understandable. Salingaros, N. (2013). It provides a design framework for community development and guidelines for new construction and improvements while protecting the city's positive characteristics Musvoto et al (2016). These elements are; buildings, streets, sidewalks, parks, neighborhoods, plazas, etc. According to Natal, K (2004) urban design combines aspects of architecture, landscape architecture, public works, public art, and transportation systems. Implementation of these urban design policies will create an inviting and attractive city with a cohesive city image that entices people to more actively use their city. However, the Urban Design seeks to achieve the following objectives in a city:

- To create an attractive, lively, and gracious city for people.

- To promote an image of quality and distinction in the harmonious blending of the natural and built environments.

- To create and develop public and semi-public spaces to attract people.

- To give visual prominence to pedestrian facilities and environments.

- To develop a functional and aesthetically pleasing urban Downtown.

- To strengthen residential neighborhood identity by defining edges and designating landmarks.

- To provide compatible transitions between areas of different land use intensity and to 'soften' new development where it adjoins less intensive uses.

- To encourage and support the arts as a vital part of community life.

- To soften the visual impact of the automobile on the city.

\subsection{Nodes}

Developed nodes are geographic points where economic or social resources/activities are (or will be) concentrated for the benefit of a community. Wang, F. Y. (2010). Nodes facilitate cost effective economic and community development efforts by pulling people, resources and certain land uses together within a close distance. Nodes / Intersections are actually the places where drivers make choices, and what is sensed at the roads are just the consequences of those choices. E. Beukes, E. et. al (2011). Intersections in cities are usually controlled by traffic lights and 
cities that exhibit high traffic demands also may employ smart traffic lights that adapt in real time to changes in the traffic system are being integrated in modern cities in order to optimize the flow of traffic Fok et. al (2012).

\subsection{Corner Shops}

A convenience/corner store is a small 'retail' business that stocks a range of everyday items such as groceries, snack foods, candy, toiletries, soft drinks, tobacco products, magazines and newspapers. Such stores may also offer money order and wire transfer services. In some jurisdictions, corner stores are licensed to sell alcohol, typically beer and wine. They differ from general stores and village shops in that they are not in a rural location and are used as a convenient supplement to larger stores. Udom, (2003)

A convenience store may be part of a gas/petrol station. It may be located alongside a busy road, in an urban area, or near a railway or railroad station or other transport hub. In some countries, convenience stores have long shopping hours, some being open 24 hours. Boberg, C. (2008). Convenience stores usually charge significantly higher prices than conventional grocery stores or supermarkets, as convenience stores order smaller quantities of inventory at higher perunit prices from wholesalers. However, convenience stores make up for this by having longer opening hours, serving more locations, and having shorter cashier lines. Max (2010)

\section{Scope and Limitation}

This study was limited to only sector 1 of the Uyo Master Plan. This is to say that, only streets (major and minor) found within the confines of Ring Road 1 will be considered as important in this exercise. More explicitly, part of Ikpa Road, Eka Street, Wellington Baasey Way, Nsikak Eduok Avenue- 4 Lane, 2 Lane, Ibrahim Badamasi Babangida (IBB) Avenue and Atiku Abubakar Way shall form the boundary of this work.

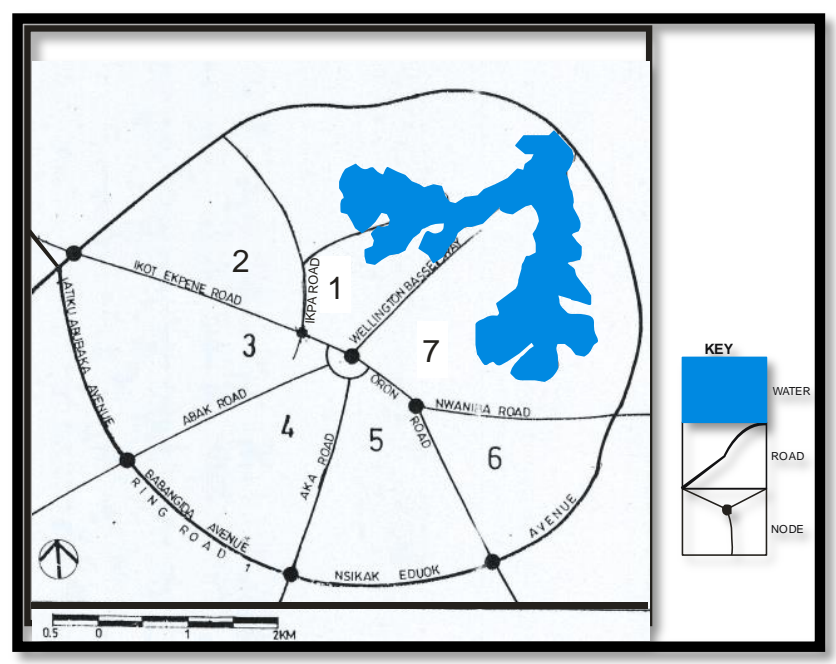

Figure 1: Sector 1 of the Uyo Master Plan Showing the 7 Subsectors Source: Ministry of Lands and Water Resources Aks. 2019

Intersections / nodes herein shall form the basis for this study. Emphasis shall be placed on commercial outlets e.g., corner shops with passive recreational services. Minimum of 50 meters along each major street shall be taken into consideration.

\section{Methodology}

The street map of Uyo forms the basis for this study, particularly sector 1 of the Master plan of Uyo. This is the space bounded by the Ring Road 1 (Atiku Abubakar Avenue, Ibrahim Badamasi Babangida (IBB) Avenue, Nsikak Eduok Avenue ( 2 and 4 lanes) and the space was stratified into 7 (seven) strata for easy studies.

This study was limited to only sector 1 of the Uyo Master Plan. This is to say that, only streets (major and minor) found within the confines of Ring Road 1 will be considered as important in this exercise. More explicitly, part of Ikpa Road, Eka Street, Wellington Baasey Way, Nsikak Eduok Avenue- 4 Lane, 2 Lane, Ibrahim Badamasi Babangida (IBB) Avenue and Atiku Abubakar Way shall form the boundary of this work. 


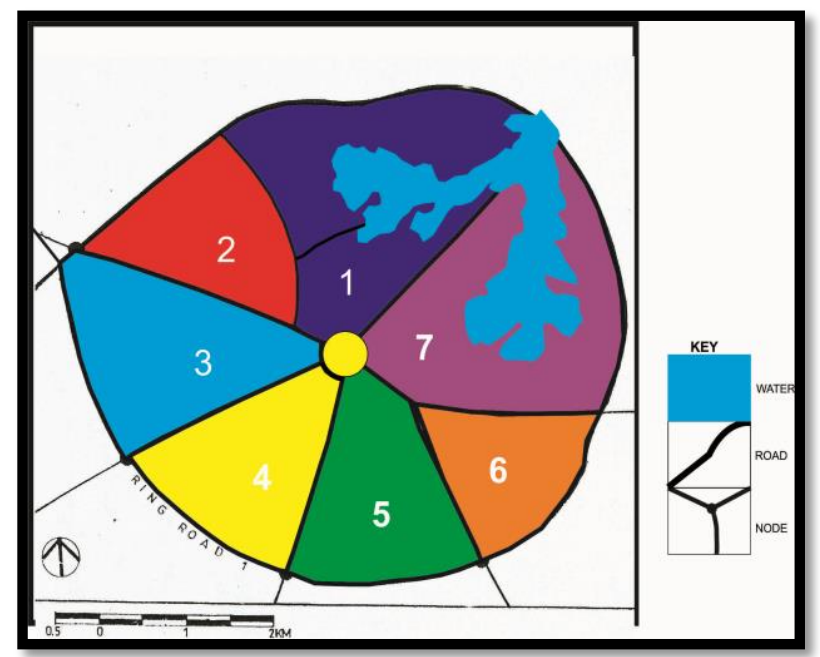

Figure 2: Seven Sub-Sectors of Sector 1 of the Uyo Master Plan Source: Ministry of Lands and Water Resources, AKS. 2019

\begin{tabular}{|c|c|c|}
\hline$S / N$ & Strata & Streets \\
\hline 1 & 1 & $\begin{array}{c}\text { 1-Ikpa Road } \\
\text { 2-Ikot Ekpene Road } \\
\text { 3-Calabar Itu Road } \\
\text { 4-Wellinton Bassey Way }\end{array}$ \\
\hline 2 & 2 & $\begin{array}{l}\text { 1-Ikot Ekpene Road } \\
\text { 2-Ikpa Road } \\
\text { 3-Calabar Itu Road }\end{array}$ \\
\hline 3 & 3 & $\begin{array}{l}\text { 1-Ikot Ekpene Road } \\
\text { 2-Atiku Abubakar Way } \\
\text { 3-Abak Road }\end{array}$ \\
\hline 4 & 4 & $\begin{array}{c}\text { 1.Abak Road } \\
\text { 2-IBB Avenue } \\
\text { 3-Aka Road }\end{array}$ \\
\hline 5 & 5 & $\begin{array}{c}\text { 1-Oron Road, } \\
\text { 2-Aka Road } \\
\text { 3-Nsikak Eduok Avenue (2 } \\
\text { lanes). }\end{array}$ \\
\hline 6 & 6 & $\begin{array}{l}\text { 1- Oron Road } \\
\text { 2-Nsikak EduokAvenue (2 lane) } \\
\text { 3-Nwaniba Road }\end{array}$ \\
\hline 7 & 7 & $\begin{array}{c}\text { 1-Nwaniba Road } \\
\text { 2-Oron Road } \\
\text { 3-Wellington Bassey Way }\end{array}$ \\
\hline
\end{tabular}

Table 1: Showing Stratum and Streets

Source: Authors Field Research, 2019

\subsection{Selection of Intersection}

The selection of intersections was carried out using simple systematic random basis. Also, corner shops shall be built at all roads' intersections after every 100 metres. 


\subsection{Selected Intersections}

\begin{tabular}{|c|c|c|}
\hline $\mathbf{S} / \mathbf{N}$ & Major Streest & Intersections \\
\hline 1 & Along Ikot Ekpene Road & $\begin{array}{l}\text { (i) Ibiam street- Ikpa road junction(ii) Udobio street } \\
\text { (iii) Iboko street junction } \\
\text { (iv) Uko Eshiet junction } \\
\text { (v) Fulga street junction } \\
\text { (vi) Ikot Ebido street junction } \\
\text { (vii) Afaha Ube junction }\end{array}$ \\
\hline 2 & Along Abak Road & $\begin{array}{l}\text { (i) Udi street junction } \\
\text { (ii) Udoeduok - Udobio streets junction } \\
\text { (iii) Iboko street - NEPA line junction } \\
\text { (iv) Nkemba street junction } \\
\text { (v) Udouweme - Ukana junction } \\
\text { (vi) Michael Abraham street junction } \\
\text { (vii) Atiku Abubakar - IBB circle Uyo. }\end{array}$ \\
\hline 3 & Along Aka Road & $\begin{array}{l}\text { (i) Nsentip - Nsasak street junction } \\
\text { (ii) Udo Eduok street junction } \\
\text { (iii) NEPA line junction } \\
\text { (iv) Obio Imo street junction } \\
\text { (v) Ukana Offot street junction } \\
\text { (vi) Akpaube street junction } \\
\text { (vii) IBB circle - Nsikak Eduok Avenue. }\end{array}$ \\
\hline 4 & Along Oron Road & $\begin{array}{l}\text { (i) Udoumana - Gibbs street junction } \\
\text { (ii) Atim Ataokpo junctiong } \\
\text { (iii) Ekpo Obot junction } \\
\text { (iv) Enwe junction } \\
\text { (v) Udotung Ubo junction } \\
\text { (vi) Aka Itiam junction } \\
\text { (vii) Nsikak Eduok 2- } 4 \text { lanes junction }\end{array}$ \\
\hline 5 & Along Nwaniba Road & $\begin{array}{l}\text { (i) Nwaniba Road - Nsikak Eduok Avenue (4 lane) junction } \\
\text { (ii) Nwaniba Road - Uruan Street Junction } \\
\text { (iii) Akpan Etuk Street } \\
\text { (iv) Udosen Uko Street } \\
\text { (v) Udobot Street } \\
\text { (VI) Ekpenyong Street. }\end{array}$ \\
\hline 6 & Along Wellington Bassey Way & $\begin{array}{l}\text { (i) Dominic Utuk Avenue } \\
\text { (ii) Akpakpan Street } \\
\text { (iii) Ekpenyong Street. }\end{array}$ \\
\hline 7 & Along Ikpa Road & $\begin{array}{l}\text { (i) Ikpa Road- Ibiam Street junction } \\
\text { (ii) Ikpa Road- Udoette junction } \\
\text { (iii) Ikpa Road by CCC junction }\end{array}$ \\
\hline
\end{tabular}

Table 2: Showing Uyo Street Map and Selected Intersections for Corner Shops Source: Authors Field Research, 2019

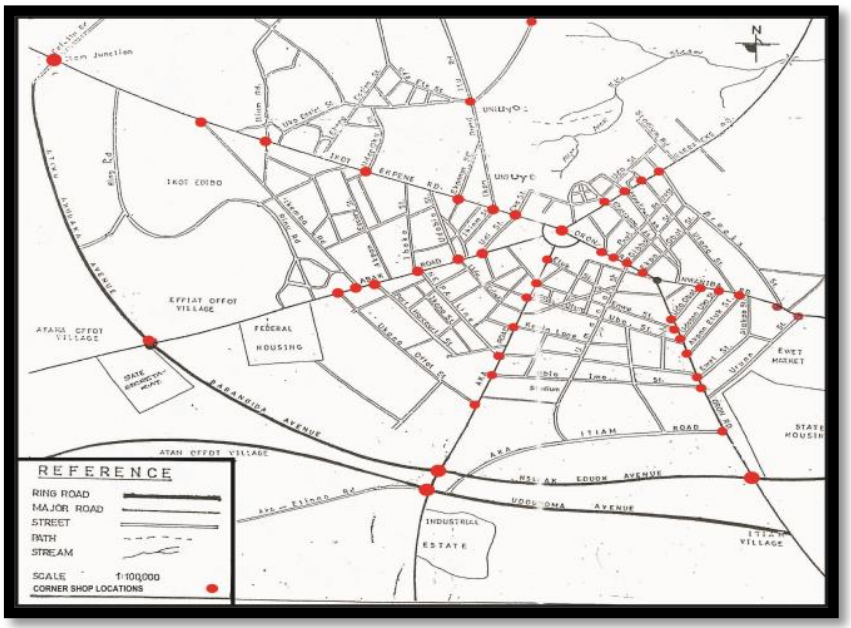

Figure 3: Selected Proposed Corner Shops Location in Uyo Source: Ministry of Lands and Water Resources Aks. 2019 
Figure 7 Sites for Corner Shops in Some Nodes in Uyo

\begin{tabular}{|c|c|c|}
\hline $\mathrm{S} / \mathrm{N}$ & Major Streest & Intersections \\
\hline 1 & $\begin{array}{l}\text { Along Ikot Ekpene Road } \\
7 \text { Corner Shops }\end{array}$ & $\begin{array}{l}\text { (i) Udi street junction } \\
\text { (ii)Ibiam street- Ikpa road junction } \\
\text { (iii) Ekpayang street junction } \\
\text { (vi)Udu Oku street junction } \\
\text { (vii)Nkemba street junction } \\
\text { (viii) Itam Road junction } \\
\text { (iv) Itam Junction }\end{array}$ \\
\hline 2 & $\begin{array}{l}\text { Along Abak Road } \\
6 \text { Corner shops }\end{array}$ & $\begin{array}{l}\text { (i) Udi street junction } \\
\text { (ii) Udoeduok - Udobio streets junction } \\
\text { (iii) Iboko street - NEPA line junction } \\
\text { (iv) Port Harcourt street junction } \\
\text { (v) Udouweme - Ukana junction } \\
\text { (vi) Atiku Abubakar - IBB circle Uyo. }\end{array}$ \\
\hline 3 & $\begin{array}{l}\text { Along Aka Road } \\
8 \text { Corner shops }\end{array}$ & $\begin{array}{l}\text { (i) Etuk StreetNsentip - } \\
\text { (ii) Enwe Street junction } \\
\text { (iii) Udotung ubo street junction } \\
\text { (iv) Kevin Lane junction } \\
\text { (v) NEPA line junction } \\
\text { (vi) Obio Imo street junction } \\
\text { (vii) Ukana Offot street junction } \\
\text { (viii) IBB circle - Nsikak Eduok Avenue. }\end{array}$ \\
\hline 4 & $\begin{array}{l}\text { Along Oron Road } \\
10 \text { Corner shops }\end{array}$ & $\begin{array}{l}\text { (i) Paul Bassy street junction } \\
\text { (ii) Gibb street junction } \\
\text { (iii) Ekpo Obot junction } \\
\text { (iv) Udobot street junction } \\
\text { (v) Udosen Uko street junction } \\
\text { (vi)Akpan Etuk street junction } \\
\text { (vii) Enwe junction } \\
\text { (viii) Obio Imo street junction } \\
\text { (ix) Aka Itiam junction } \\
\text { (x) Nsikak Eduok 2- } 4 \text { lanes junction }\end{array}$ \\
\hline 5 & $\begin{array}{l}\text { Along Nwaniba Road } \\
\text { 6 Corner shops }\end{array}$ & $\begin{array}{l}\text { (i) Nwaniba Road - Nsikak Eduok Avenue (4 lane) junction } \\
\text { (ii) Nwaniba Road - Uruan Street Junction } \\
\text { (iii) Akpan Etuk Street } \\
\text { (iv) Udosen Uko Street } \\
\text { (v) Udobot Street } \\
\text { (vi) Ekpenyong Street. }\end{array}$ \\
\hline 6 & $\begin{array}{c}\text { Along Wellington Bassey Way } \\
3 \text { Corner shops }\end{array}$ & $\begin{array}{l}\text { (i) Dominic Utuk Avenue } \\
\text { (ii) Akpakpan Street } \\
\text { (iii) Ekpenyong Street. }\end{array}$ \\
\hline 7 & $\begin{array}{l}\text { Along Ikpa Road } \\
3 \text { Corner shops }\end{array}$ & $\begin{array}{l}\text { (i) Ikpa Road- Ibiam Street junction } \\
\text { (ii) Ikpa Road- Udoette junction } \\
\text { (iii) Ikpa Road by CCC junction }\end{array}$ \\
\hline
\end{tabular}

Table 3: Showing Sites for Corner Shops in Uyo

Source: Authors Field Research, 2015

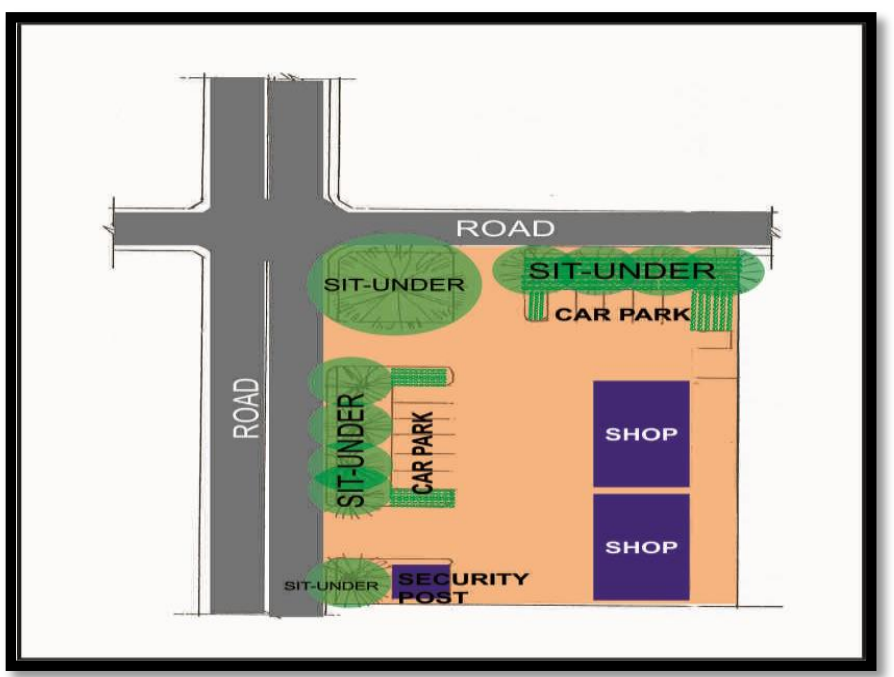

Figure 4: Design of the Corner Shop

Source: Author's Design, 2019 
Figure 2. Site Plan for the Corner Shop

The layout of the corner shop shall incorporate shopping malls, parking spaces, sit - outs, security point which will give a beautiful impression of the streetscape in Uyo Urban.

\subsubsection{Shopping Mall}

Shopping malls should be situated along every street that make - up the intersection (be it cross (+) road or ' $\mathrm{T}$ ' junction). Provision should be made 1 to 2 shopping malls along each street

\subsubsection{Parking Lots}

In front of the shops, there should be parking lots for both temporary and permanent parking for both private and commercial vehicles. The parking should be either $90^{\circ}, 60^{\circ}$ or $45^{\circ}$ as would be permitted by the space available.

\subsubsection{Sit - Outs}

Sit - Outs should be provided as well for persons who intend to wait for another, or for any person who may be waiting for any services. This Sit - Out could be made of concrete planter - sit - under to enable the user sit under a shed, facing the streets or facing any other location according to the designer's choice. The design of the seats could be concrete, hand wood or metal make according to the designer's choice.

\subsubsection{Security Point}

In order to provide needed security service to the users of this corner shop, the law enforcement agents (police officers) should be employed to check and control the activities of the hoodlums who perambulate the streets.

\subsubsection{Conveniences / Sanitary Services}

There should be toilet facilities herein to enable the users ease themselves, should there be need to urinate or excrete. Refuse disposal and waste control should also be considered important in the provision of this corner shops. Waste receptacle and evacuation by the state Ministry of Environment and National Resources.

\subsubsection{Utility -Lighting and Portable Water}

In order to provide adequate lighting in the corner shops, the providers of street lighting should be constant lighting within corner shop as well as the services of the water co - operation to provide constant running water to maintain neatness of the toilet system and stand -pips for persons intending to fetch water with containers.

\subsubsection{Drainage}

Proper drainage should be provided to direct storm/run-off water into the drain channels to avoid stagnant/surface water on the floor. The depth and width of the drains should be determined by the construction engineer and in accordance with the existing drainage pattern of the area.

\subsubsection{Landscaping}

Both hardscape and soft cape landscape elements would be used to create a decent environment for the corner shop. Hard cape element: pavements concrete floors, bitumen or asphalts granites gravels sand, stones, metals, plastic, wood, etc. where necessary shall be used to crate functional spaces as would be found needful in the area. While Softscape elements: Plant material trees, grasses and flowering plants shall be used to reduce the hardness of the landscape materials in a good harmonious relationship.

\subsubsection{Management of the Corner Shop}

The corner shops shall be managed and maintained by the State Government through the efforts of the Ministry of housing and Urban Renewal. Continuous efforts shall be made to control and maintain the corner shops to avoid wastage and depreciations.

\section{Conclusion}

The provision of corner shop is variety (supporting facility) introduced into streetscape improvement to ensure that demand and supply take place effectively within Uyo metropolis. Corner shops to a greater extent would provide the people with opportunities of commercial together with recreational activities and parking lots in Uyo metropolis as well as boost the revenue base of the government. This would enhance the beautification of the streetscapes and improve the city character of Uyo metropolis.

\section{Recommendations}

- Provision should be made at selected intersections for either 1 or 2 corner shops, well designed to incorporate parking lots, recreational activities, security, and public conveniences.

- Revenue charge on these shops should be minimal to the extent that shop users be able to pay at ease.

- Proper maintenance culture should be given by the management agencies to ensure quality protection and to avoid rust/ depreciation in order that this project may stand a taste of time. 


\section{References}

i. AlabiM and Akinbode (2010). Towards Effective Physical Planning in Local Governments in Nigeria. Journal of Environmental Research 4(2): 173 - 176

ii. Beukes, E, Vanderschuren M and Zuidgeest M (2011). Context Sensitive Multimodal road Planning: A Case Study in Cape Town, South Africa. Journal of Transport Geography 19(3): 452 - 460

iii. Ekandem S, Daudu P, Lamidi R., and Ayegba M (2014). Roles and Challenges to Urban Planning. Journal of Sustainable Development Studies 6 (2014)

iv. Fok C, Hanna M, Gee S, Stone P. Julien C (2012): A Patform for Evaluating Autonomous Intersection Management Policies. Proceeding of the IEEE/ACM Third International Conference on Cyber- Physical Pp 87 - 96

v. Idowu 0, (2013). Challenges of Urbanization and Urban Growth in Nigeria. American Journal of Sustainable Cities and Society 2(1):79 - 95

vi. Musvoto, G., Lincoln, G. and Hansmann, R (2016). The Role of Spatial Development Frameworks in Transformation of the The Kwini Municipality, KwaZulu-Natal, South Africa: Reflecting on 20 Years of Planning. Urban Forum 27, 187-210

vii. Natal, K (2004). South Africa Spatial development framework.

viii. MaxC.(2010) The Godzone Dictionary: of Favourite New Zealand Words and Phrases. Exisle Publishing.

ix. Olujimi J (2009). Evolving a Planning Strategy for Managing Urban Sprawl in Nigeria. Journal of Human Ecology 25(3): 201 - 208

x. Salingaros, N (2013). Theory of Urban Web: Journal of Urban Design 5(3): 291 - 316

xi. Udom, E (2003). Design Concepts of the Environment: An approach in the Master Plan for Uyo Capital City. Maiden Conference/Exhibition, Faculty of Environmental Studies, University of Uyo, Uyo.

xii. United Nation (2018). World Urbanization Prospects. http://creativecommons.org/licenses/by/3.0/igo/

xiii. Usoro, E (2010). Akwa Ibom State: Geographical Perspective. Usoro, E. and Akpan, P. (eds). Enugu: Immaculate Publishers. Pp 16 - 30

xiv. Wang, F (2010). Parallel Control and Management for Intelligent Transportation System: Concepts, Architecture, and Applications. Journal of IEEE 11(3): 630 - 638 